JURNAL ILMIAH KEBIDANAN IMELDA

Vol.7, No.2, September2021, pp.47-52

ISSN: 2597-7180 (Online), 2442-8116 (Print)

http://jurnal.uimedan.ac.id/index.php/JURNALKEBIDANAN

\title{
PENGARUH MASASE PUNGGUNG TERHADAP PENGURANGAN NYERI PERSALINAN: A SYSTEMATIC REVIEW
}

\author{
Nova Linda Rambe ${ }^{1}$, Khairani ${ }^{2}$ \\ ${ }^{1,2}$ Universitas Imelda Medan, Indonesia
}

\section{Article Info \\ Article history: \\ Received Aug 24, 2021 \\ Revised Sep 10, 2021 \\ Accepted Sep 20, 2021}

\section{Keywords:}

Back Massage

Labor Pain

\begin{abstract}
Labor pain is a natural process. There are $12-67 \%$ of pregnant women will feel anxious about pain during childbirth. As an effort to reduce labor pain is massage. Pain is a condition of a person's discomfort on a scale or level, the way that can be done in tackling the pain scale is by means of back massage. Doing back massage at the time of delivery is believed to be very effective but in reality back massage is not done because they do not know that back massage can reduce pain. This research method uses a systematic review with the aim of seeing its effectiveness in overcoming labor pain. This systematic review method was taken by reviewing articles and journals published through the google scoolar site from 7 journals. Based on the results of this study, it can be concluded that back massage can reduce the intensity of pain in labor.
\end{abstract}

This is an open access article under the CC BY-SAlicense.

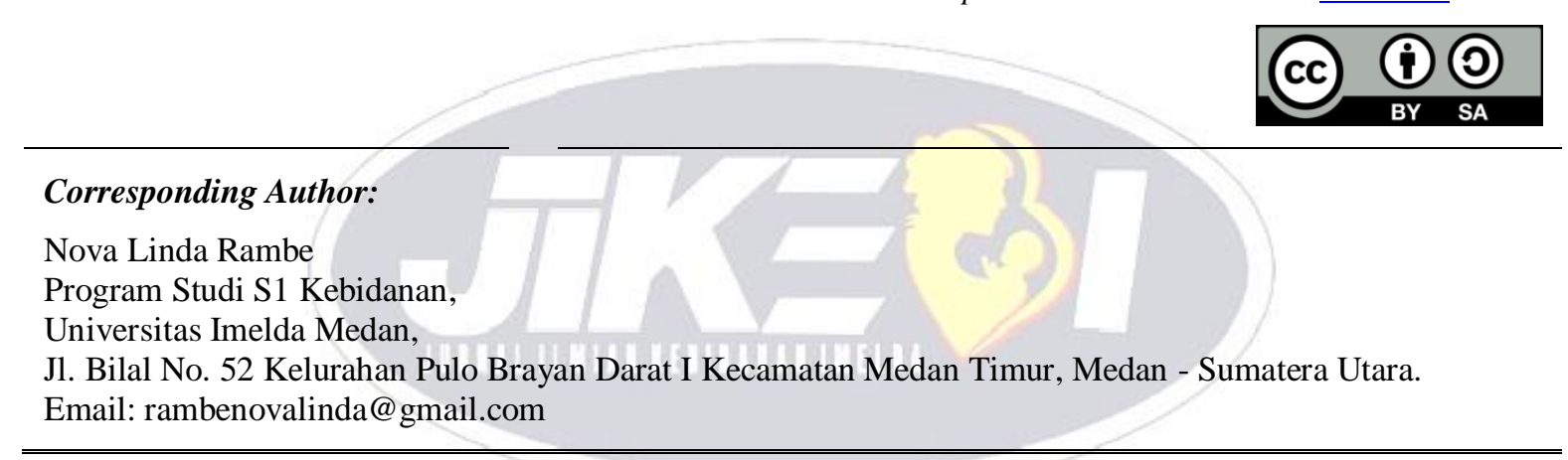

\section{INTRODUCTION}

Proses persalinan tidak lepas dari derita perih yang akan diderita oleh setiap wanita, dimana sebagian besar persalinan disertai rasa nyeri. Nyeri pada masa melahirkan adalah hal yang alamiah. Nyeri tidak jarang pula menyebabkan ibu merasakan kecemasan yang berlebihan dan merasa tidak mampu melewati proses persalinan. Sebuah penelitian terbaru terdapat sebanyak $67 \%$ ibu hamil merasa sedikit takut, 12\% merasa sangat takut dan 23\% sama sekali tidak takut pada sakit saat melahirkan (Cunningham, 2013).

Nyeri ialah suatu kondisi di mana seseorang merasakan perasaan tidak nyaman yang berbeda-beda pada skalanya, dan hanya orang tersebutlah yang dapat menjabarkan rasa nyeri yang dirasakannya (Hidayat, 2006). Nyeri pada persalinan akan meningkatkan emosi yang dapat mengakibatkan pelepasan hormon yang lebih seperti katekolamin dan steroid engan akibat vasokontriksi pembuluh darah sehingga kontraksi uterus melemah.

Nyeri saat melahirkan yang sangat sakit dan lama dapat mempengaruhi peningkatan peredaran darah maupun menurunkan energi yang harus mendapatkan penanganan secara cepat dan tepat agar ibu dan janin dapat terselamatkan. Rasa nyeri persalinan yang tinggi dapat menimbulkan kecemasan. Saat ini banyak ibu saat persalinan kurang mendapatkan penanganan dalam upaya menurunkan rasa nyeri, yang dapat menyebabkan persalinan lama yang dapat menguras tenaga ibu.

Masase punggung atau penekanan tulang sakrum merupakan salah satu metode dalam menurunkan nyeri pada proses melahirkan. Pada teori menunjukkan masa sepunggung sangat baik dilakukan selama persalinan, seperti penggosokan badan bagian belakang terutama dilakukan pada saat terjadinya upaya untuk 
melancarkan proses keluarnya bayi dari rahim melalui leher rahim atau bervariasi dalam hal bermacam pegangan dan tempat. Efek pengendalian nyeri hanya berlangsung selama masase dilakukan.

Berdasarkan latar belakang diatas maka perlu dilakukannya tinjauan systematic review yang mengidentifikasikan metode untuk mengurangi sakit yang terjadi dalam proses persalinan. Systemic review ini juga mengambil cara yang manjur dalam pengurangan derita perih pada proses persalinan.

\section{RESEARCH METHOD}

Metode yang dipakai adalah systematic review. Sumber data penelitian ini merupakan bahan bacaan yang di peroleh dari hasil penelitian (artikel penelitian) tentang pengaruh massase punggung dapat mengurangi nyeri pada saat persalinan. Penelitian ini dilakukan secara media elektronik dengan database google shcolar. Inti dari pengurangan rasa nyeri persalinan yaitu masase punggung. Setelah artikel tersebut di temukanmelaluipencarian google scholar selanjutnya di evaluasi sesuai criteria yaitu teknik mengurang rasa nyeri persalinan dan di telaah untuk di review sejumlah 7 artikel.

\section{RESULTS AND ANALYSIS}

3.1. Hasil

Analisa Univariat

1. Tingkat Nyeri Responden Sebelum Dilakukan Masase Punggung

Tabel 1. Tingkat Nyeri Responden Sebelum Dilakukan Masase Punggung

\begin{tabular}{|c|c|c|c|}
\hline \multicolumn{2}{|c|}{ Nyeri Sebelum Masase Punggung } & \multicolumn{2}{|c|}{ Nyeri Sesudah Masase Punggung } \\
\hline Tingkat nyeri & Frek & Tingkat Nyeri & Frek \\
\hline \multirow[t]{2}{*}{ Nyeri Sedang } & 15 & Nyeri Sedang & 7 \\
\hline & & Nyeri Ringan & 8 \\
\hline \multirow[t]{3}{*}{ Nyeri Berat } & 18 & Nyeri Berat & 6 \\
\hline & & Nyeri Sedang & 11 \\
\hline & & Nyeri Ringan & 1 \\
\hline Nyeri Sangat Berat & 2 & Nyeri Berat & 2 \\
\hline Total & 35 & Total & 35 \\
\hline
\end{tabular}

2. Tingkat Nyeri Responden Sesudah Dilakukan Masase Punggung

Tabel 2. Tingkat Nyeri Responden Sebelum Dilakukan Masase Punggung

\begin{tabular}{lclc}
\hline \multicolumn{2}{c}{ Nyeri Sebelum Masase Punggung } & \multicolumn{2}{c}{ Nyeri Sesudah Masase Punggung } \\
\hline \multicolumn{1}{c}{ Tingkat Nyeri } & Frek & \multicolumn{1}{c}{ Tingkat Nyeri } & Frek \\
\hline Nyeri Sedang & \multirow{2}{*}{15} & Nyeri Sedang & 7 \\
\cline { 3 - 4 } & & Nyeri Ringan & 8 \\
\hline \multirow{2}{*}{ Nyeri Berat } & \multirow{2}{*}{ Notal } & Nyeri Berat & 6 \\
\cline { 3 - 4 } & & Nyeri Sedang & 11 \\
\cline { 2 - 4 } & & Nyeri Ringan & 1 \\
\hline Nyeri Sangat Berat & $\mathbf{3 5}$ & Nyeri Berat & $\mathbf{3 5}$
\end{tabular}

\section{Analisa Bivariat}

Pada analisis bivariate merupakan analisis untuk menguji hipotesis dan untuk mengetahui pengaruh tindakan masase punggung terhadap pengurangan nyeri kala I fase aktif persalinan.

Tabel 3. Uji Hipotesis

\begin{tabular}{cccccc}
\hline Kelompok & $\begin{array}{c}\text { Nyeri Sebelum } \\
\text { Masase }\end{array}$ & $\begin{array}{c}\text { Nyeri Sesudah } \\
\text { Masase }\end{array}$ & Beda & $\mathbf{Z}$ & P Value \\
\hline 6.94 & 4.74 & 22 & -4.456 & 0.00 \\
\hline
\end{tabular}

\subsection{Pembahasan}

Metode pencarian yang telah dilakukan dari 7 jurnal penelitian didapatkan bahwa masase punggung dapat mengurangi rasa nyeri pada proses persalinan. Adapun hasil penelitian yang didapat dari menelaah 7 jurnal yang direview adalah sebagai berikut:

1. Teknik Massage Punggung Dapat Mengurangi Nyeri Persalinan di Bidan Praktek Swasta Tri Handayani Gebog Kabupaten Kudus

Hasil penelitian (Puspitasari, 2017) ciri khas ibu yang melahirkan meliputi usia, belajar di sekolah dan paritas. Pada responden umur $<20$ tahun serta $>35$ tahun menunjukkan masih banyak ibu melahirkan yang 
memiliki bahaya tinggi dalam persalinan karena umur responden yang terlalu muda dan terlalu tua. Sedangkan pada tingkat pendidikan, dari 21 ibu yang menjadi sampel hanya terdapat 2 orang yang berpendidikan SD, ini menunjukkan masih ada beberapa orang yang berpendidikan rendah sehingga kurang mengetahui pengetahuan mengenai persalinan dan teknik masase punggung digunakan untuk pengurangan rasa nyeri. Sementara 21 ibu yang menjadi sampel terdapat 10 orang adalah primipara. Karena primipara adalah seorang wanita yang melahirkan anak pertamanya sehingga tidak mempunyai pengalaman tentang persalinan dan teknik pengurangan rasa nyeri.

Dari 21 orang ibu ada ibu yang berhasil mengurangi rasa nyeri yang hebat. Pada saat ibu akan melahirkan tidak diberikan tindakan massage punggung, dari 12 orang ibu $(57,1 \%)$ ada 1 orang ibu bersalin $4,8 \%$ yang merasakan sakit yang kuat dan lama setelah dilakukan tindakan pijatan punggung. Ini menunjukkan teknik masase cukup manjur dalam menurunkan rasa nyeri yang hebat pada persalinan. Secara statistik didapatkan $\mathrm{p}=0,000$, masase punggung berpengaruh terhadap penurunan derita perih ada awal mula akan terjadinya persalinan.

Metode ini sejalan dengan penelitian (Mei-Yuch Chang, 2002), menyebutkan bahwa pijatan selama 30 menit pada bahu dan punggung yang dilakukan pada awal akan melahirkan dapat mengurangi nyeri dan memberikan dukungan psikologis pada saat proses persalinan.

Begitu juga dengan hasil penelitian (Aryani, 2015) didapatkan ibu yang sudah di masase punggung memiliki rasa nyeri lebih rendah 29,62 poin dari pada ibu yang tidak dimasase, nilai $p=0,001$ yang berarti ada pengaruh pijatan punggung terhadap penurunan rasa nyeri dan kadar endokrin pada ibu melahirkan awal persalinan normal.

2. Pengaruh Masase Pungung Terhadap Penurunan Rasa Nyeri Kemajuan Pembukaan $1 \mathrm{~cm}$ Sampai $3 \mathrm{~cm}$ Pada Persalinan Normal

Hasil penelitian (Sofia, 2015) dengan desain penelitian ini pre-experimental. Sampel sebanyak 13 responden yang memenuhi kriteria inklusi. Teknik sampling secara accidental sampling. Analisa data menggunakan Fisher's Exact.

Hasil uji "Fisher's Exact" didapatkan nilai p =0,013 ( $<<0,05)$, ini artinya H0 di tolah dan H1 di terima. Maka disimpulkan bahwa ada dampak pijatan punggung dalam penurunan pengurangan derita perih pada saat awal akan melahirkan normal ibu primigravida.

Merujuk pada pembahasan sebelumnya, pijat punggung yang dilakukan pada responden di kategorikan menjadi 2 yaitu pijat punggung yang sesuai SOP dan pijat punggung yang tidak sesuai dengan SOP. Pijat yang dilakukan sesuai dengan SOP lebih berpengaruh untuk menurunkan pengurangan derita perih pada saat awal akan melahirkan dari pada pijat punggung yang tidak dilakukan sesuai SOP dikarenakan responden tidak meminta untuk melakukan pijatan pada daerah yang derita perih dan tidak membentuk huruf $\mathrm{V}$ terbalik. Hal ini yang menyebabkan pijat punggung tidak bisa mengurangi intensitas nyeri yang di alami.

Berdasarkan hasil tersebut di atas sehingga terjadi proporsi yang diambil dari beberapa ide dapat disimpulkan bahwa masase punngung berpengaruh terhadap penurunan derita perih pada awal persalinan ibu primigravida di BPS Tibyani Halim, S.ST Kecamatan Asembagus Kabupaten Situbondo tahun 2014. Sehingga perlu adanya peningkatan pelayanan kesehatan khususnya asuhan sayang ibu pada saat proses persalinan sehingga ibu dapat dilewati dengan baik dan menyenangkan tanpa ada komplikasi yang menyertai.

3. Efektifitas Pijat Punggung Pada Rasa Nyeri Persalinan Kemajuan Pembukaan $1 \mathrm{~cm}$ Sampai $3 \mathrm{~cm}$ Di

Rumah Bersalin Suko Asih Kabupaten Sukoharjo

Hasil Penelitian (Rahayuningsih, 2019) menggunakan desain deskriptif kualitatif dengan pendekatan proses keperawatan (nursing process) di Rumah Bersalin Suko Asih Sukoharjo. Populasi penelitian adalah ibu inpartu dengan persalinan normal pada fase Kemajuan pembukaan $1 \mathrm{~cm}$ sampai $3 \mathrm{~cm}$. Sampel sebanyak 5 orang ibu dengan ciri-ciri inklusi: Perempuan, usia 20-40 tahun Primipara/Multipara, memiliki score Skala Nyeri 0-10 (Comparative Pain Scale) sedikitnya 1 dan tidak memiliki riwayat patah tulang, sakit / luka pada area punggung, dan tidak ada indikasi penyakit lainnya.

Berdasarkan hasil penelitian subjek yang berumur paling muda mengalamin yeri lebih berat dibandingkan dengans ubjek yang berumur paling tua. Subjek pada usia 21 tahun dan 24 tahun mengalami nyeri skala 9 sedangkan subjek yang berumur 26, 27 dan 33 tahun mengalami nyeri skala 8. Sesuai pendapat (Rumbin, 2008), maka usia akan berpengaruh terhadap tingkat nyeri persalinan, usia ibu yang terlalu muda saat melahirkan maka tingkat nyeri akan semakin tinggi apabila usia ibu melahirkan pada saa tusia reproduksi sehat. Keadaan kekencangan rahim ibu lebih tinggi dibanding ibu dengan usia $<20$ tahun khususnya pada saat melahirkan anak pertama sehingga nyeri yang dirasakanakan lebih lama. 
4. Pengaruh Massase Punggung Terhadap Adaptasi Rasa Nyeri Persalinan Pembukaan dari $3 \mathrm{~cm}$ Sampai Lengkap, Lama fase Dilatasi Serviks Lengkap $10 \mathrm{~cm}$ dan Keluarnya Darah Saat Melahirkan Pada Ibu

Primigravida.

Berdasarkan hasil penelitian (Rahmawati, 2015) Jenis penelitian quasi eksperiment design. Subyek dalam metode penelitian ini adalah semua ibu primigravida yang bersalin pada pembukaan dari $3 \mathrm{~cm}$ sampai lengkap di Puskesmas Magelang Selatan. Dengan kriteria Inklusi meliputi: usia 20-35 tahun, ketuban belum pecah, tidak dalam pengaruh analgesik dan bersedia menjadi responden.

Ibu primigrafida berjumlah 40 oarang. Karakteristik responden penelitian pada variable usia dapat peneliti laporkan dimana pada beberapa ibu melakukan masase punggung memiliki umur rata-rata 24 tahun dengan umur termuda 16 tahun dan umur tertua 31 tahun. Hal ini tidak jauh berbeda pada kelompok kontrol yang memiliki rata-rata umur 24 tahun dengan umur termuda 19 tahun dan umur tertua 31 tahun.

Tingkat nyeri responden yang mendapatkan perlakuan masa sebelakang badan, pada Kemajuan pembukaan $1 \mathrm{~cm}$ sampai $3 \mathrm{~cm}$ menyatakan bahwa sakit yang mereka rasakan berkisar pada rentang sakit sedang. Sedangkan pada kelompok yang tidak mendapatkan perlakuan masih terdapat 30 persen responden yang merasakan nyeri berat pada pembukaan dari $3 \mathrm{~cm}$ sampai lengkap.

Dalam masa lama Fase dari dilatasi serviks lengkap $10 \mathrm{~cm}$ dapat terdapat $90 \%$ ibu melahirkan yang dilakukan pijatan punggung dapat melakukan persalinan bayi dalam setengah jam pertama ketika pembukaan serviks sudah $10 \mathrm{~cm}$. Sementara ibu bersalin yang tidak mendapat perlakuan pijatan punggung terdapat $40 \%$ yang melahirkan pada fase dari dilatasi serviks lengkap $10 \mathrm{~cm}$ setengah jam pertama. Pada kelompok perlakuan tidak ditemukan responden yang melahirkan fase dari dilatasi serviks lengkap $10 \mathrm{~cm}$ dengan jangka waktu 1 sampai 1,5 jam, kemudian pada ibu bersalin yang tidak mendapatkan perlakuan ada 5 persen yang menyelesaikan fase dari dilatasi serviks lengkap $10 \mathrm{~cm}$ pada waktu ini.

Ada Pengaruh masase punggung terhadap penurunan derita perih dari pembukaan $3 \mathrm{~cm}$ sampai pembukaan $10 \mathrm{~cm}$, lama melahirkan fase dari dilatasi serviks lengkap $10 \mathrm{~cm}$ dan keluarnya darah saat melahirkan pada ibu yang baru pertama kali melahirkan dengan p value masing-masing 0,01 . Sementara $z$ hitung untuk rasa nyeri $-4,112$, lama persalinan fase dari dilatasi serviks lengkap $10 \mathrm{~cm}-4,023$ dan perdarahan $-3,949$.

5. Perbedaan Skala Nyeri pada Ibu Inpartu Kemajuan Pembukaan $1 \mathrm{~cm}$ Sampai $3 \mathrm{~cm}$ Pembukaan dari $3 \mathrm{~cm}$

Sampai Lengkap dengan Masase Punggung dan Tanpa Masase Punggung

Penelitian Kiftiyah dengan jenis penelitian yang digunakan adalah Desain penelitian yang digunakan dalam penelitian ini adalah penelitian pra-eksperimental static-group comparison design. Sampel ibu inpartu Kemajuan pembukaan $1 \mathrm{~cm}$ sampai 3 cmpembukaandari $3 \mathrm{~cm}$ sampai lengkap yang dilakukan masase punggung dan tidak dilakukan masase punggung di RB Hikmah Tambakagung Kabupaten Mojokerto. Teknik sampling yang digunakan dalam penelitian ini, pengambilan sampel menggunakan tehnik consecutive sampling.

Berdasarkan Uji Wilcoxon, maka ada perbedaan skala nyeri pada ibu inpartu kemajuan pembukaan 1 $\mathrm{cm}$ sampai $3 \mathrm{~cm}$ pembukaan dari $3 \mathrm{~cm}$ sampai lengkap dengan masase punggung dan tanpa masase punggung dengan hasil uji statistik 0.034. Hasil penelitian diketahui bahwa dengan masase punggung sebagian besar $(66,7 \%)$ responden mempunyai skala nyeri ringan, sedangkan tanpa masase punggung sebagian besar $(66,7 \%)$ responden mempunyai skala nyeri sedang. Ada perbedaan skala nyeri pada ibu inpartu kemajuan pembukaan $1 \mathrm{~cm}$ sampai $3 \mathrm{~cm}$ pembukaan dari $3 \mathrm{~cm}$ sampai lengkap dengan masase punggung dan tanpa masase punggung di RB Hikmah Tambakagung Kabupaten Mojokerto dengan hasil uji statistik 0,034 $(<0,05)$.

6. Pengaruh Masase Punggung Terhadap Intensitas Rasa nyeri Kemajuan Pembukaan $1 \mathrm{~cm}$ Sampai $3 \mathrm{~cm}$ Fase Laten Persalinan Normal Melalui bertambahnya Endorfin Dalam Tubuh

Penelitian Aryani (2015) penelitian experimental dengan post test only control group design yang dibagi beberapa kelompok perlakuan yang sudah melakukan masase pada punggung dan kelompok kontrol yang tidak melakukan masase punggung. Intensitas rasa nyeri dinilai dengan kuisioner dan kadar endorphin diukur dengan human beta endorfin Elisa Kit. Data dianalisis menggunakan uji t-test independent dan korelasi Spearmen.

Hasil penelitian ini telah ditemukan ibu bersalin yang melakukan masase memiliki intensitas nyeri lebih rendah 29.62 point dari pada yang tidak dimasas enilai $p=0.001$, masase punggung berpengaruh terhadap intensitas nyeri Kemajuan pembukaan $1 \mathrm{~cm}$ sampai $3 \mathrm{~cm}$ persalinan normal. Ibu bersalin yang dimasase memiliki endorfin lebih tinggi dari pada yang tidak dimasase sebesar $142.82 \mathrm{pcg} / \mathrm{ml}$ nilai $p=0.001$ masase punngung berpengaruh dengan kadar endokrin dalam tubuh. Ada pengurangan kadar endorphin dengan penurunan intensitas nyeri dengan nilai $\mathrm{r}=0,795$ dan nilai $p=0.001$. Kesimpulan dari penelitian ini adalah masase pada punggung sangat berpengaruh terhadap pengurangan rasa nyeri dan kadar endorfin ibu bersalin 
kemajuan pembukaan $1 \mathrm{~cm}$ sampai $3 \mathrm{~cm}$ fase laten persalinan normal serta kadar endorphin berkorelasi dengan pengurangan rasa nyeri kemajuan pembukaan $1 \mathrm{~cm}$ sampai $3 \mathrm{~cm}$ fase laten persalinan normal.

7. Masase Punggung Sangat Berpengaruh Terhadap Pengurangannya Rasa Nyeri Pada Persalinan Kemajuan Pembukaan $1 \mathrm{~cm}$ sampai $3 \mathrm{~cm}$ Pembukaan dari $3 \mathrm{~cm}$ Sampai Lengkap pada Ibu Bersalin Normal di BPM Wilayah Kerja Puskesmas Tegalrejo Kabupaten Magelang

Penelitian (Handayani, 2012) bertujuan untuk mengetahui pengaruh masase punggung pada pengurangan rasa nyeri pada persalinan di BPM wilaya kerja puskesmas tegal rejo. Peneliti melakukan penelitian pra-eksperimental menggunakan one-group pra test post test design yaitu mengungkapkan hubungan sebab akibat dengan cara melibatkan satu kelompok subjek, dimana kelompok subjek di observasi sebelum dilakukan intervensi, kemudian diobservasi lagi setelah intervensi. Jumlah populasi dalam penelitian ini adalah $35 \mathrm{ibu}$ bersalin.

Hasil penelitian adalah tingkat nyeri ibu bersalin normal. Kemajuan pembukaan $1 \mathrm{~cm}$ sampai $3 \mathrm{~cm}$ pembukaan dari $3 \mathrm{~cm}$ sampai lengkap persalinan sebelum dilakukan teknik masase punggung sebagian besar mempunyai nyeri tingkat berat yaitu 18 atau 51,4\% responden. Tingkat nyeri ibu bersalin normal kemajuan pembukaan $1 \mathrm{~cm}$ sampai $3 \mathrm{~cm}$ pembukaan dari $3 \mathrm{~cm}$ sampai lengkap persalinan sesudah dilakukan teknik masase punggung sebagian besar mempunyai nyeri tingkat sedang yaitu 20 atau 57,2\% responden, tingkat nyeri ringan yaitu $25,7 \%$ atau 9 responden dan tetap mengalami nyeri berat sebanyak 17,1\% atau 6 responden.

Ada pengaruh masase punggung terhadap pengurangan nyeri Kemajuan pembukaan $1 \mathrm{~cm}$ sampai $3 \mathrm{~cm}$ pembukaan dari $3 \mathrm{~cm}$ sampai lengkap persalinan pada ibu bersalin normal dengan harga $\mathrm{Z}$ hitung sebesar 4,456 dengan uji 2 pihak maka nilai signifikansi p value sebesar 0,00 dimana $\mathrm{P}<\alpha 0,05$.

\section{CONCLUSION}

Berdasarkan penelitian review dapat disimpulkan bahwa untuk mengurangi rasa nyeri persalinan, adalah dengan melakukan masase punggung (pijat punggung). Berdasarkan hasil systematic review ini bidan, para petugas kesehatan di wilayah puskesmas melakukan metode ini untuk mengurangi rasa nyeri pada ibu bersalin dengan teknik masase punggung (pijat punggung).

\section{REFERENCES}

Aryani, Yeni. 2015. Pengaruh teknik Masase Punggung Terhadap Intensitas Nyeri Kemajuan pembukaan 1 cm sampai $3 \mathrm{~cm}$ Fase Laten Persalinan Normal Melalui Peningkatan Kadar Endorfin. Jurnal Kesehatan Andalas. Volume 4, Nomor 1.

Aziz, Alimul. 2006. Pengantar Kebutuhan Dasar Manusia. Jakarta: Salemba Medika Handerson.

Christine.2005. Buku Ajar Konsep Kebidanan. Jakarta: EGC.

Handayani, Esti. 2012. Pengaruh Masase Punggung Terhadap Pengurangan Nyeri Persalinan Kemajuan pembukaan $1 \mathrm{~cm}$ sampai $3 \mathrm{~cm}$ Pembukaan dari $3 \mathrm{~cm}$ sampai lengkap pada Ibu Bersalin Normal di BPM Wilayah Kerja Puskesmas Tegal rejo Kabupaten Magelang. Jurnal Kebidanan. Volume IV. Nomor 02.

Ilmiah, WS. 2015. Buku Ajar Asuhan Persalinan Normal. Yogyakarta: Nuha Medika.

Kiftiyah. Perbedaan Skala Nyeri pada Ibu Inpartu Kemajuan pembukaan $1 \mathrm{~cm}$ sampai $3 \mathrm{~cm}$ Pembukaan dari $3 \mathrm{~cm}$ sampai lengkap dengan Masase Punggung dan Tanpa Masase Punggung. Jurnal Keperawatan dan Kebidanan. Stikes Dian Husada Mojokerto.

Mander, R. 2004. Nyeri Persalinan. Jakarta: EGC.

Mansjoer, A. 2000. Kapita Selekta Kedokteran. Jakarta: Media Aesculapius.

Marpaung, L.M., 2011. Gambaran Kecemasan dan Nyeri Persalinan pada Ibu Primigravida di Klinik Bersalin Sally, KTI, Medan: Universitas Sumatera Utara, Fakultas Keperawatan.

Nanda. 2015. Diagnosis Keperawatan: Definisi dan Klasifikasi 2015-2017. Jakarta: EGC.

Nolan, M. 2003. Kehamilan \& Melahirkan. Jakarta: Arcan.

Rahmawati, Wiwin Reny. 2013. Pengaruh masase Punggung terhadap Rasa Nyeri Persalinan Pembukaan dari $3 \mathrm{~cm}$ sampai lengkap Lama Fase dari dilatasi serviks lengkap $10 \mathrm{~cm}$ dan Perdarahan Persalinan pada Primigravida. Jurnal Kesehatan Masyarakat Nasional. Volume 8. Nomor 5.

Saifuddin, A.B. 2002. Buku Panduan Nasional Pelayanan Kesehatan Maternal dan Neonatal. Jakarta Bina Pustaka Sarwono Prawirohardjo.

Simkin, Penny. 2005. Buku Saku Persalinan. Jakarta: EGC. 


\section{BIOGRAPHIES OF AUTHORS}

\begin{tabular}{l|l|} 
Nova Linda Rambe, Gelar D-III diperoleh dari Akademi Kebidanan Darmo, Jurusan \\
Kebidanan pada tahun 2009. Gelar D-IV diperoleh dari Universitas Padjadjaran, \\
Jurusan Kebidanan Tahun 2011. Magister Kebidanan diperoleh dari Universitas \\
Padjadjaran, Jurusan Kebidanan pada tahun 2017. Saat ini aktif sebagai dosen tetap di \\
Prodi S1 Kebidanan Universitas Imelda Medan dan menjabat sebagai Ketua Program \\
Studi.
\end{tabular}

